\title{
Cu(II) 4-phenoxybenzoate dimers and monomer coordinated by pyridines: synthesis and crystal structures.
}

Marta Sánchez-Sala, ${ }^{a}$ Josefina Pons, ${ }^{a}$ Angel Alvarez-Larena, ${ }^{b}$ Laura Bayés-García, ${ }^{c}$ Mercè Font-

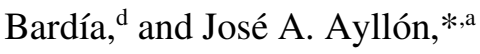

${ }^{a}$ Departamento de Química, Universidad Autónoma de Barcelona, 08193-Bellaterra,

Barcelona, Spain

${ }^{b}$ Servicio de Difracción de Rayos X, Universidad Autónoma de Barcelona, 08193 Bellaterra, Barcelona, Spain.

${ }^{c}$ Mineralogia, Petrologia i Geologia Aplicada, Universitat de Barcelona, Martí i Franquès s/n, 08028-Barcelona, Spain.

${ }^{d}$ Unitat de Difracció de Raig-X, Centres Científics i Tecnològics de la Universitat de Barcelona (CCiTUB), Universitat de Barcelona, Solé i Sabarís, 1-3, 08028-Barcelona, Spain.

Keywords: 4-Phenoxybenzoate, Copper(II) paddle-wheel, Copper(II) monomer, Pyridine ligands, Supramolecular networks 


\begin{abstract}
The complexes $\left[\mathrm{Cu}(\mathrm{PhOBz})_{2}(\mathrm{dPy})\right]_{2}(\mathrm{PhOBz}=4$-phenoxybenzoate; $\mathrm{dPy}=$ pyridine $(\mathbf{1})$, 3-phenylpyridine (2), 4-benzylpyridine (3) and 4-phenylpyridine (4) and the complex $\left[\mathrm{Cu}(\mathrm{PhOBz})_{2}(4-\mathrm{Phpy})_{2}\left(\mathrm{H}_{2} \mathrm{O}\right)\right](5)$ were prepared and fully characterized. X-ray crystal structures of the five complexes have been determined. Complexes 1-4 consist of binuclear units where both $\mathrm{Cu}(\mathrm{II})$ are linked by four syn-syn carboxylate bridges, showing a paddle-wheel unit. The compound $\mathbf{5}$ is mononuclear and the metal center is coordinated to two $\mathrm{PhOBz}$ in monodentate form, two 4-Phpy ligands and one $\mathrm{H}_{2} \mathrm{O}$ molecule with slightly distorted square pyramidal geometry. Finally, the magnetic properties of compounds $\mathbf{3}$ and $\mathbf{5}$ have also been studied, confirming the different strength interactions between $\mathrm{Cu}(\mathrm{II})$ cations.
\end{abstract}




\section{Introduction}

Coordination compounds have attracted great attention with regard to their structural variety. The framework structure of the coordination compounds depend the central metal ions and the functionality of the ligands. Aside from coordination bonding interactions, hydrogen bonding and $\pi-\pi$ stacking interactions, solvent molecules, counterions, and the ratio of metal salt to organic ligands and templates are also an influence on the ultimate architectures [1-3].

The carboxylates ligands play an important role in coordination chemistry, adopting diverse binding modes: terminal monodentate, chelating to one metal center, bridging bidentate in a syn-syn, syn-anti and anti-anti configurations to two metal centers, and bridging tridentate to two metal centers [4-6]. In particular, copper (II) carboxylates have been extensively studied, being the $\left[\mathrm{Cu}(\mathrm{RCOO})_{2} \mathrm{~L}\right]_{2}$ paddle-wheel type dinuclear topology, where L is an apical ligand with oxygen or nitrogen atom the most frequently characterized. These complexes, and in particular, complexes including pyridines derivatives as apical ligands have garnered great interest due to their diverse structural features spectroscopic, magnetic and catalytic activities [7-13].

The crystallization of paddle-wheel like dimers competes with the formation of mononuclear species. The dimer-monomer equilibrium in $\mathrm{Cu}(\mathrm{II})$ carboxylate derivatives with pyridines or other auxiliary ligands has been known since decades and thoroughly studied [14-16]. The nature of the carboxylate ligand joint to the use of additional ligands determines the nuclearity and topological features of the formed compounds. However, reports in the literature where the monomeric and dimeric structures for the same choice ligands are isolated and characterized are scarce [17-18]. 
In this context, our group has studied the synthesis and structural characterization of the $\left[\mathrm{Cu}\left(\mu-\mathrm{MeCO}_{2}\right)_{2}\left(\mathrm{H}_{2} \mathrm{O}\right)\right]_{2}$ with derivatives amine ( $\mathrm{dPy}=3$-phenylpyridine, 2benzylpyridine, and 4-acetylpyridine), obtaining paddle-wheel complexes $[\mathrm{Cu}(\mu-$ $\left.\left.\mathrm{MeCO}_{2}\right)_{2}(\mathrm{dPy})\right]_{2}$, replacing the $\mathrm{H}_{2} \mathrm{O}$ molecule for different pyridine ligands [19]. However, with 4-phenylpyridine, a monomeric compound has been obtained $\left[\mathrm{Cu}\left(\mathrm{MeCO}_{2}\right)_{2}(4-\mathrm{Phpy})\left(\mathrm{H}_{2} \mathrm{O}\right)_{2}\right]\left[\mathrm{Cu}\left(\mathrm{MeCO}_{2}\right)_{2}(4-\mathrm{Phpy})\left(\mathrm{H}_{2} \mathrm{O}\right)\right][20]$.

We are interested in the synthesis and characterization of the complexes using carboxylate and amine ligands, with the finality of studying their supramolecular interactions, in particular H-bond and $\pi-\pi$ stacking. Previously, we have studied the reaction of the $\left[\mathrm{Cu}\left(\mu-\mathrm{MeCO}_{2}\right)_{2}\left(\mathrm{H}_{2} \mathrm{O}\right)\right]_{2}$ with 1,3-benzodioxole-5-carboxylic acid (HPip) and bulky pyridines ( $\mathrm{dPy}=3$-phenylpyridine, 4-benzylpyridine, and 4-phenylpyridine) obtaining paddle-wheel $\left[\mathrm{Cu}(\mathrm{Pip})_{2}(\mathrm{dPy})\right]_{2}$ and monomeric $\left[\mathrm{Cu}(\mu-\mathrm{Pip})_{2}(\mathrm{dPy})\left(\mathrm{H}_{2} \mathrm{O}\right)_{\mathrm{x}}\right](\mathrm{x}=$ 1,2) compounds from the same reaction mixture, except for 4-Phpy, in this case, only the dimeric compound $\left[\mathrm{Cu}(\mu \text {-Pip)(4-Phpy })_{2}\right]_{2}$ was obtained. The study of the crystal structure of the former complexes show that the dioxole ring of piperonylic acid has a key role in the intermolecular interactions, whereas $\pi$ - $\pi$ stacking interactions plays a minor role [21].

As a continuation of this study we have focused our interest in the ligand 4phenoxybenzoic acid (HPhOBz) that contains a diaryl ether group. In the literature, reports of 4-phenoxybenzoate complexes are very scarce, with only $\operatorname{Co}($ II) $[22,23]$, $\mathrm{Mn}(\mathrm{II})[24,25]$ and $\mathrm{Pd}(\mathrm{IV})[26,27]$ compounds been reported and characterized. Moreover, complexes with the ligand 2-phenoxybenzoic acid have been described in the literature only for $\mathrm{Mn}$ (II) [28] and Fe(III) [29] compounds. To our knowledge, no $\mathrm{Cu}(\mathrm{II})$ compound containing these ligands have been reported in the literature. 
Here in, we present five $\mathrm{Cu}$ (II) 4-phenoxybenzoate $\mathrm{Cu}$ (II) complexes that include different pyridine derivatives as secondary coordination ligand. All compounds have been obtained by wet-chemistry reaction in methanol as solvent and at room temperature. The five complexes were characterized by elemental analyses, IR spectroscopy and X-ray crystal structure. The supramolecular networks generated from intermolecular interactions are discussed.

\section{Results and discussion}

\subsection{Synthesis and general characterization}

Complexes 1-5 were prepared in $\mathrm{MeOH}$ at room temperature via combination of the $\mathrm{Cu}\left(\mathrm{MeCO}_{2}\right)_{2} \cdot \mathrm{H}_{2} \mathrm{O}$, 4-phenoxybenzoic acid $(\mathrm{HPhOBz})$ and pyridine derivatives $(\mathrm{dPy}=$ pyridine (py) (1), 3-phenylpyridine (3-phpy) (2), 4-benzylpyridine (4- $\left.\mathrm{PhCH}_{2} \mathrm{py}\right)$ (3) or 4-phenylpyridine (4-Phpy) $(\mathbf{4 , 5})$ ligands, using 1:2:4 Cu:HPhOBz:dPy molar ratio. Pyridine derivatives were used in excess to neutralize the acetic acid formed (Scheme 1).

Using py, 3-Phpy or 4-PhCH 2 py green paddle-wheel compounds were obtained $\left[\mathrm{Cu}(\mathrm{PhOBz})_{2}(\mathrm{dPy})\right]_{2}(\mathbf{1 - 3})$, while when 4-Phpy is used as a ligand different behavior is observed. Thus, using 4-Phpy as secondary ligand a mixture of solids appears, a green paddle-wheel binuclear $\left[\mathrm{Cu}(\mathrm{PhOBz})_{2}(4-\mathrm{Phpy})\right]_{2}(\mathbf{4})$, that is obtained in a very low yield, and, in a much higher yiels, a blue mononuclear compound $\left[\mathrm{Cu}(\mathrm{PhOBz})_{2}(4-\right.$ Phpy $\left.)_{2}\left(\mathrm{H}_{2} \mathrm{O}\right)\right]$ (5). In the reaction media used, both compounds precipitated simultaneously, the size of the crystals allows isolating pure samples by careful manual separation. A similar behavior was observed in the reaction of $\mathrm{Cu}\left(\mathrm{MeCO}_{2}\right)_{2} \cdot \mathrm{H}_{2} \mathrm{O}$, 
piperolinic acid (HPip) and 3-phenylpyridine (3-Phpy) or 4-benzylpyridine (4$\mathrm{PhCH}_{2}$ py), but in this case the two compounds precipitate successively [21].

Pure 4 can also be obtained by treating 5 with ethanol after prolonged agitation of the suspension. This transformation, impliying elimination of half of the pyridine ligand and dehydratation; this behavior is similar to that observed for $\left[\mathrm{Cu}\left(\mathrm{MeCO}_{2}\right)_{2}(4-\right.$ Phpy) $\left.\left(\mathrm{H}_{2} \mathrm{O}\right)_{2}\right]\left[\mathrm{Cu}\left(\mathrm{MeCO}_{2}\right)_{2}(4-\mathrm{Phpy})\left(\mathrm{H}_{2} \mathrm{O}\right)\right]$ to $\left[\mathrm{Cu}\left(\mathrm{MeCO}_{2}\right)_{2} \text { (4-Phpy) }\right]_{2}$ [20] but while transformation proceeds very quickly for the later compound, in the case of $\mathbf{4}$ is much slower.

The five compounds were characterized by elemental analyses, FTIR-ATR spectroscopy and single-crystal X-ray diffraction. The elemental analyses for the five compounds are in agreement with the proposed formula.

The FTIR-ATR spectra of compounds 1-4 display the characteristic carboxylate bands in the range $1572-1570 \mathrm{~cm}^{-1}$, typical for $v_{\text {as }}\left(\mathrm{CO}_{2}\right)$ and $1399-1392 \mathrm{~cm}^{-1}$ for $v_{\mathrm{s}}\left(\mathrm{CO}_{2}\right)(\mathrm{SI}$, Figure S1). The difference $(\Delta)$ between $v_{\mathrm{as}}\left(\mathrm{CO}_{2}\right)$ and $v_{\mathrm{s}}\left(\mathrm{CO}_{2}\right)$ for four compounds is 172 (1), $179(2), 178(3), 177(4) \mathrm{cm}^{-1}$, indicating a bridging coordination mode of the carboxylate group of the 4-phenoxybenzoic acid [30,31]. In $\mathbf{5}$, the $v_{\text {as }}\left(\mathrm{CO}_{2}\right)$ band appears at $1600 \mathrm{~cm}^{-1}$, and the $v_{\mathrm{s}}\left(\mathrm{CO}_{2}\right)$ band at $1371 \mathrm{~cm}^{-1}$. The difference $(\Delta)$ is $229 \mathrm{~cm}^{-1}$, suggesting a monodentate coordination mode for the carboxylate group [30,31]. For this compound, also a broad band appears at $3299 \mathrm{~cm}^{-1}$ attributable to $v(\mathrm{O}-\mathrm{H})$, which is consistent with the presence of $\mathrm{H}_{2} \mathrm{O}$ in the structure. The shape and position of this band suggest that the $\mathrm{O}-\mathrm{H}$ group participates in a hydrogen bond interaction $[32,33]$. Absence of a band at $1720-1690 \mathrm{~cm}^{-1}$ in the five spectra indicates that the carboxylic acid is deprotonated in the corresponding compounds. The bands attributable to the aromatic groups $v(\mathrm{C}=\mathrm{C})_{\mathrm{ar}}, v(\mathrm{C}=\mathrm{N})_{\mathrm{ar}}, \delta(\mathrm{C}-\mathrm{H})_{\mathrm{ip}}$ and $\delta(\mathrm{C}-\mathrm{H})_{\text {oop }}$ are also observed $[34,35]$. The IR 
spectral data thus clearly support the structures determined by the X-ray diffraction method.

\subsection{Molecular structures of the compounds 1-5}

The compound $\mathbf{1}$ crystallizes in the orthorhombic Pbca, the compound $\mathbf{2}$ in the monoclinic $\mathrm{P} 2{ }_{1} / \mathrm{c}$ and the compounds 3 and $\mathbf{4}$ in the triclinic $\mathrm{P}(-1)$ space groups. A perspective view of 1-4 is shown in Figure 1. Selected bond distances and angles are provided in Table 1 and Table 2.

The crystal structure of compounds $\mathbf{1 - 4}$ in a centrosymmetric binuclear copper(II) units and are typical of binuclear $\left[\mathrm{M}(\text { carboxylate })_{2} \mathrm{~L}\right]_{2}$ complexes, in which the carboxylate groups of the acetate ligands display a paddle-wheel-like arrangement, with four bridging acetate ligands in a syn-syn coordination mode. The $\mathrm{Cu}$ atoms adopt a $\left[\mathrm{CuO}_{4} \mathrm{~N}\right]$ coordination mode with four oxygen atoms from four different 4phenoxybenzoic units and one nitrogen atom of the py, 3-Phpy or 4- $\mathrm{PhCH}_{2}$ py ligands. The carboxylate display a paddle-wheel-like arrangement about the $\mathrm{Cu} \cdots \mathrm{Cu}$ axis. The $\mathrm{Cu} \cdots \mathrm{Cu}$ separation in 1-4 compounds are 2.6198(5), 2.6462(4), 2.6524(6) and 2.6579(10) A, respectively, with values comparable to those reported for paddle-wheel complexes with similar structure [19,21,36-40].

Each $\mathrm{Cu}(\mathrm{II})$ ion adopts a slightly distorted square-pyramidal environment $(\tau=0.15$ (1), $0.067(2), 0.034(3)$ and 0.80 (4) [41]), coordinated equatorially to four carboxylate oxygen atoms [Cu-O: 1.967-1.978 $\mathrm{A}$ (1); 1.965-1.981 $\AA$ (2); 1.9560-1.982 $\AA$ (3); $1.956-$ $1.981 \AA$ (4)] and apically py, 3-Phpy, 4-PhCH 2 py or 4-Phpy [Cu-N: 2.146(2) $\AA$ (1); 2.1682(13) $\AA$ (2); 2.144(2) $\AA$ (3); 2.169(4) $\AA$ (4)]. The angles O-Cu-O are between $88.42-91.00^{\circ}(\mathbf{1}) ; 89.17-89.92^{\circ}(\mathbf{2}) ; 88.19-90.64^{\circ}(\mathbf{3}) ; 89.39-90.05^{\circ}(\mathbf{4})$. The metal atoms 
are displaced in the axial direction towards the amine molecules from the oxygen plane, as indicated by the $\mathrm{O}-\mathrm{Cu}-\mathrm{N}$ angles, with the values in the range from $93.05-97.97^{\circ}(\mathbf{1})$; $92.59-99.26^{\circ}(2) ; 93.33-99.00^{\circ}(3) ; 92.26-100.13^{\circ}(4)$.

The compound $\mathbf{5}$ crystallizes in the monoclinic C2/c space group. A perspective view of 5 is shown in Figure 2. Selected bond distances and angles are provided in Table 2. The asymmetric unit contains only a PhOBz and a 4-PhPy ligands, and half water ligand, other half molecule generated by a $\mathrm{C} 2$ symmetry axis that overlaps the $\mathrm{Cu}-\mathrm{O}_{\text {water }}$ bond. The $\mathrm{Cu}(\mathrm{II})$ has a $\left[\mathrm{CuO}_{3} \mathrm{~N}_{2}\right]$ core in a distorted square pyramidal geometry $(\tau=16.87)$ [41]. The basal plane is defined by two crystallographic equivalent oxygen atoms provided by two monodentate PhOBz ligands $(\mathrm{Cu}(1)-\mathrm{O}(11)=1.9346(16) \AA)$ and two equivalents nitrogen atoms provided by a pair of 4-Phpy ligands in trans disposition $(\mathrm{Cu}(1)-\mathrm{N}(31)=2.027(2) \AA)$. The apical position is occupied by a coordinated $\mathrm{H}_{2} \mathrm{O}$ molecule $(\mathrm{Cu}(1)-\mathrm{O}(10)=2.266(3) \AA)$. The distortion can be observed from the bond angles and from the separation of the atoms in relation to mean plane that contains the four atoms coordinated to metal center and the $\mathrm{Cu}$ atom $(\mathrm{Cu}(1),-0.0725(4) \AA$; $\mathrm{O}(11)$ and $\mathrm{O}(11)^{\prime},-0.1456(18) \AA$; $\mathrm{N}(31)$ and $\mathrm{N}(31)^{\prime}, 0.1819(18) \AA$ ). The dihedral angle between the carboxylate groups and basal plane is $81.27^{\circ}$. The pyridine ring of $4-\mathrm{PhPy}$ is twisted $57.14(11)^{\circ}$ respect to the basal plane, and the benzoate $76.86(8)^{\circ}$. Both rings of 4-PhPy are only slightly bend respect to each other $\left(5.31(16)^{\circ}\right)$. The dihedral angle between pyridine ring from 4-Phpy and benzoate groups is $85.97(12)^{\circ}$. These values are comparable with similar structures described in the literature [20,21,42-45].

\subsection{Supramolecular structures for compounds $\mathbf{1 - 5}$}

In compound 1, three different $\mathrm{C}-\mathrm{H} \cdots \mathrm{O}$ intermolecular hydrogen bonding interactions are observed. The shortest hydrogen bond is established between the oxygen atoms of 
the ether group of a PhOBz ligand a hydrogen atom of the pyridine ring located at meta position. The propagation of these interactions generates $2 \mathrm{D}$ supramolecular sheets that are interconnected by additional hydrogen bonds yielding a compact 3D arrangement (Table 3, Fig. 3).

In the other three paddle wheel dimers (2-4), oxygen atoms from the ether group of half of the PhOBz ligands also participate as acceptors in intermolecular hydrogen bonding, the donor being a hydrogen of the phenyl ring of 3-Phpy ligand in 2, a pair of neighbor hydrogen atoms, in ortho and meta position of the 4-PhCH 2 py in $\mathbf{3}$, and hydrogen atoms in meta position of the benzoic ring in $\mathbf{4}$. The expansion of these contacts generates 1D chains in every structure, parallel to $a$ axis in $\mathbf{2}$, to $b$ axis in $\mathbf{3}$ and to $c$ axis in $\mathbf{4}$ (Fig. 4).

In compound 5, the coordinated $\mathrm{H}_{2} \mathrm{O}$ molecule plays a key role. Each $\mathrm{H}_{2} \mathrm{O}$ molecule shows two symmetrical H-bonds that connect its hydrogens atoms with non-coordinated oxygens of the PhOBz ligand of an adjacent molecule (Table 3). This interaction defines chains in $b$ direction with $\mathrm{Cu}(\mathrm{II}) \cdots \mathrm{Cu}(\mathrm{II})$ distances being 5.9746(6) $\AA$. Only a reduced number of similar structures (ca. 15), containing monodentate benzoate derivative, pyridine derivative and one molecule of water per $\mathrm{Cu}$ (II) cation have been reported. In all these structures, the chains were defined by $(\mathrm{Cu}-\mathrm{O}-\mathrm{C}-\mathrm{O} \cdots \mathrm{H}-\mathrm{O}-\mathrm{H} \cdots \mathrm{O}-\mathrm{C}-\mathrm{O}-)$ rings. The carboxylate plane is twisted respect to the plane containing the two $\mathrm{O}$ atoms the copper and the oxygen of the water molecule as usually found in similar structures [20,21,42,46-48] (Fig. 5).

\subsection{Magnetic properties of compounds $\mathbf{3}$ and $\mathbf{5}$.}

Compound $\mathbf{3}$ was selected as a representative example of dimer family of compounds. The $\chi_{\mathrm{p}} \mathrm{T}$ for compound $\mathbf{3}$ values reach a maximum at around $300 \mathrm{~K}$ and decreases upon 
cooling (Figure 6). This behaviour is characteristic of the strong antiferromagnetic $\mathrm{Cu} \cdots \mathrm{Cu}$ interaction in paddle-wheels dimers [50]. The magnetic behaviour of this compound can be modelled according to the classical Bleany and Bowers $S=1 / 2$ dimer model [49]. Found parameters are: $g=2.02 ; J\left(\mathrm{~cm}^{-1}\right)=-284 ; \rho(\%)=6.57 ; \mathrm{H}=-\mathrm{JS}_{\mathrm{i}} \mathrm{S}_{\mathrm{i}+1}$. Magnetic susceptibility data of $\left[\mathrm{Cu}(\mathrm{PhOBz})_{2}(\mathrm{PhPy})_{2}\left(\mathrm{H}_{2} \mathrm{O}\right)\right](\mathbf{5})$, denotes that $\mathrm{Cu}(\mathrm{II})$ centers did not interact significantly at room temperature $\left(\mu_{\mathrm{eff}}=2.3 \mathrm{mB}\right.$ at $\left.300 \mathrm{~K}\right)$. This behavior has previously been described for $\mathrm{Cu}$ (II) compounds with similar structure, by measuring susceptibility data on decreasing temperature $[45,47,51]$. The observed steady decrease of the effective magnetic moment with temperature indicates some degree of interaction between the copper centers (Fig. 7a). Data can be fitted to the Curie-Weiss law in the $300-70 \mathrm{~K}$ range (Figure $7 \mathrm{~b}$ ), with $\mathrm{C}=0.820 \mathrm{emu} \cdot \mathrm{K} \cdot \mathrm{mol}^{-1}$, and $\theta=-88 \mathrm{~K}$, denoting an antiferromagnetic interaction.

\section{Conclusion}

The reaction of $\left[\mathrm{Cu}\left(\mu-\mathrm{MeCO}_{2}\right)_{2}\left(\mathrm{H}_{2} \mathrm{O}\right)\right]_{2}$ and 4-phenoxybenzoic acid and different pyridine in methanol at room temperature yields green dimers and/or blue monomer including coordinated water in function of the pyridine derivative present. When py (1), 3-PhPy (2) and 4- $\mathrm{PhCH}_{2} \mathrm{Py}(3)$ are used, only a unique compound was obtained, while when 4-Phpy is used, a mixture of compounds $(\mathbf{4 , 5})$ was obtained. The crystal structure confirmed that compounds $\mathbf{1 - 4}$ present a paddle-wheel $\mathrm{Cu}(\mathrm{II})$ structure, with four bridging 4-PhOBz ligands in a syn-syn coordination mode disposition. Compound $\mathbf{5}$ is monomeric, the $\mathrm{Cu}(\mathrm{II})$ atom is coordinated to two phenoxibenzoate ligand in monodentate form, two pyridines and one $\mathrm{H}_{2} \mathrm{O}$ in the apical position. The intermolecular interactions are relatively weak in all the dimers, the participation of oxygen atom of the ether group of $\mathrm{PhOBz}$ ligand as hydrogen acceptor is observed in all 
the cases. Finally, water molecule in $\mathbf{5}$ determines the formation of one dimensional supramolecular chains which much shorter hydrogen bonds. In this compound, $\mathrm{Cu}(\mathrm{II})$ centers do not interact significantly at room temperature.

\section{Experimental}

\subsection{Materials and generals details}

$\mathrm{Cu}$ (II) acetate monohydrate $\left(\mathrm{Cu}\left(\mathrm{MeCO}_{2}\right)_{2} \cdot \mathrm{H}_{2} \mathrm{O}\right)$, 4-phenoxybenzoic acid (4-HPhOBz), pyridine (py), 3-phenylpyridine (3-Phpy), 4-benzylpyridine(4- $\left.\mathrm{PhCH}_{2} \mathrm{py}\right)$ and 4phenylpyridine (4-Phpy) ligands and methanol (MeOH) as solvent, were purchased from Sigma-Aldrich and used with further purification.

All reactions and manipulation were carried out in air. Elemental analyses $(\mathrm{C}, \mathrm{H}, \mathrm{N})$ were carried out by the staff of Chemical Analysis Service of the Universitat Autònoma de Barcelona on a Thermo Scientific Flash 2000 CHNS Analyses. FTIR-ATR spectra were recorded on a Tensor 27 (Brucker) spectrometer, equipped with an attenuated total reflectance (ATR) accessory model MKII Golden Gate with diamond window in the range $4000-600 \mathrm{~cm}^{-1}$. Powder XRD patterns were measured at room temperature with a Siemens D5000 apparatus using the $\mathrm{CuK} \alpha$ radiation. Patterns were recorded from $2 \theta=$ 5 to $50^{\circ}$, with a step scan of $0.02^{\circ}$ counting for $1 \mathrm{~s}$ at each step. Magnetic measurements from 5 to $300 \mathrm{~K}$ were performed in a Quantum Design MPMS-5S SQUID susceptometer. The molar susceptibility was corrected for the sample holder and for the diamagnetic contribution of all atoms by means of Pascal's tables [52]. 
A solution of $1.92 \mathrm{mmol}$ of pyridine derivative (py, $152 \mathrm{mg}$; 3-Phpy; $298 \mathrm{mg}$; 4$\left.\mathrm{PhCH}_{2} \mathrm{py}, 325 \mathrm{mg}\right)$ and $\mathrm{HPhOBz}(0.963 \mathrm{mmol} ; 206 \mathrm{mg})$ in methanol (10 mL) was added over a solution of $\mathrm{Cu}\left(\mathrm{MeCO}_{2}\right)_{2} \cdot \mathrm{H}_{2} \mathrm{O}(0.481 \mathrm{mmol} ; 96.0 \mathrm{mg})$ in methanol (20 $\mathrm{mL})$. In all cases, the resulting solution is blue and when it was concentrated, a green crystalline solid precipitate. The three compounds were filtered, washed with cold methanol $(5 \mathrm{~mL})$ and dried under air. The precipitates solids obtained are crystalline and a single crystal of good quality was selected directly from each sample.

1. Yield: $152 \mathrm{mg}(56 \%)$. Anal. Calc. for $\mathrm{C}_{62} \mathrm{H}_{46} \mathrm{~N}_{2} \mathrm{O}_{12} \mathrm{Cu}_{2}: \mathrm{C}, 65.39 ; \mathrm{H}, 4.07 ; \mathrm{N}, 2.46$. Found: C, 65.07; H, 4.02; N, 2.47\%. IR (ATR, $\left.\mathrm{cm}^{-1}\right)$ v: 3049, 1620, 1603, 1584, 1571 $v_{\mathrm{as}}(\mathrm{COO}), 1486,1399 v_{\mathrm{s}}(\mathrm{COO}), 1237,1160,1098,1070,1037,1012,870,798,777$, $750,692,652,630$.

2. Yield: $262 \mathrm{mg}$ (84\%). Anal. Calc. for $\mathrm{C}_{74} \mathrm{H}_{54} \mathrm{~N}_{2} \mathrm{O}_{12} \mathrm{Cu}_{2}$ : C, 68.88; H, 4.22; N, 2.17. Found: C, 68.62; H, 4.28; N, 2.19\%. IR (ATR, $\left.\mathrm{cm}^{-1}\right)$ v: 3068, 1621, 1585, 1572 $v_{\text {as }}(\mathrm{COO}), 1486,1393 v_{\mathrm{s}}(\mathrm{COO}), 1237,1165,1154,1098,1075,1028,1011,870,800$, $781,751,691,652,634$.

3. Yield: $177 \mathrm{mg}$ (56\%). Anal. Calc. for $\mathrm{C}_{76} \mathrm{H}_{58} \mathrm{~N}_{2} \mathrm{O}_{12} \mathrm{Cu}_{2}$ : C, 69.24; H, 4.43; N, 2.12. Found: C, 68.84; H, 4.43; N, 2.14\%. IR (ATR, $\mathrm{cm}^{-1}$ ) v: 3062, 1616, 1608, 1585, 1570 $v_{\text {as }}(\mathrm{COO}), 1488,1392 v_{\mathrm{s}}(\mathrm{COO}), 1226,1157,1070,1059,871,796,779,752,692,655$, 613.

4.3 Synthesis of the compounds $\left[\mathrm{Cu}(\mathrm{PhOBz})_{2}(4-\mathrm{Phpy})\right]_{2}(4)$ and $\left[\mathrm{Cu}(\mathrm{PhOBz})_{2}(4-\mathrm{Phpy})\right.$ $\left.\left(\mathrm{H}_{2} \mathrm{O}\right)\right](5)$

To a solution 4-Phpy (1.92 mmol, $298 \mathrm{mg})$ and HPhOBz (0.963 mmol; $206 \mathrm{mg})$ in methanol $(20 \mathrm{~mL})$, a solution of $\mathrm{Cu}\left(\mathrm{MeCO}_{2}\right)_{2} \cdot \mathrm{H}_{2} \mathrm{O}(0.481 \mathrm{mmol} ; 96.0 \mathrm{mg})$ in methanol $(10 \mathrm{~mL})$ was added. The resulting green solution was allowed to evaporate at room 
temperature. When the solution volume was reduced a crystalline green and blue mixture of solids appears. The mixture of solids was washed twice with cold methanol $(5 \mathrm{~mL})$ and dried under air.

4. Yield: $25 \mathrm{mg}(8 \%)$. Anal. Calc. for $\mathrm{C}_{74} \mathrm{H}_{54} \mathrm{~N}_{2} \mathrm{O}_{12} \mathrm{Cu}_{2}$ : C, 68.88; $\mathrm{H}, 4.22 ; \mathrm{N}, 2.17$. Found: C, 68.67; H, 4.22; N, 2.15\%. IR (ATR, $\left.\mathrm{cm}^{-1}\right)$ v: 3058, 1606, 1587, 1571 $v_{\text {as }}(\mathrm{COO}), 1486,1394 v_{\mathrm{s}}(\mathrm{COO}), 1234,1161,1099,1072,1010,873,837,798,750,690$, $652,619$.

5. Yield: $125 \mathrm{mg}$ (40\%). Anal. Calc. for $\mathrm{C}_{48} \mathrm{H}_{38} \mathrm{~N}_{2} \mathrm{O}_{7} \mathrm{Cu}_{2}$ : C, 70.45; H, 4.68; N, 3.42. Found: C, 70.74; H, 4.75; N, 4.38\%. IR (ATR, $\left.\mathrm{cm}^{-1}\right)$ v: $3299 v(\mathrm{O}-\mathrm{H}), 1600 v_{\mathrm{as}}(\mathrm{COO})$, $1585,1560,1483,1411,1371 v_{\mathrm{s}}(\mathrm{COO}), 1230,1161,1093,1078,1045,1014,916,871$, $837,777,767,752,727,692,644,622$.

\section{$4.4 X$-ray structure determination}

Adequate prism-like crystals were used for single crystal X-ray diffraction experiments, green crystals in the case of compounds $\mathbf{1 - 4}$, and a blue crystal in the case of compound 5. Data were collected using Mo $\mathrm{K}_{\alpha}$ radiation in a D8 Venture system equipped with a multilayer mono-chromate and a Mo microfocus (structures $\mathbf{1}$ and 2) and in a SMARTAPEX diffractometer (structures 3-5). An empirical absorption correction was applied (SADABS). The structure was solved by direct methods (SHELXNT) and refined by full-matrix least-squares methods on $F^{2}$ for all reflections (SHELXL-2016) [53]. Nonhydrogen atoms were refined using anisotropic displacement parameters. Hydrogen atoms bonded to carbon atoms were placed in calculated positions with isotropic displacement parameters fixed at 1.2 times the $U_{e q}$ of the corresponding carbon atoms. In compound 5, the only crystallographic independent hydroxylic hydrogen atom was 
located in a difference Fourier map and its position and its isotropic displacement parameter were refined.

Crystal data and further refinement details are presented in Tables 4 and 5. Molecular graphics were generated with the program Mercury $3.6[54,55]$. Color codes for all molecular graphics: blue $(\mathrm{Cu})$, light blue $(\mathrm{N})$, red $(\mathrm{O})$, grey $(\mathrm{C})$, white $(\mathrm{H})$.

\section{Acknowledgements}

This work was financed by the Spanish National Plan of Research MAT201565756-R and CTQ2017-83632 and by 2017SGR1687 projects from the Generalitat de Cataluña.

\section{Appendix A. Supplementary data}

CCDC 1836973-1836977 contains the supplementary crystallographic data for

1-5. These data can be obtained free of charge via http://www.ccdc.cam.ac.uk/conts/retrieving.html, or from the Cambridge Crystallographic Data Centre 12 Union Road, Cambridge CB2 1 EZ, UK; fax: (+44) 1223-336-033; or e-mail: deposit@ccdc.cam.ac.uk. 


\section{References}

[1] J. J. Perry IV, J. A. Perman, M. J. Zaworotko, Chem. Soc. Rev. 38 (2009) 14001417.

[2] J. R. Li, J. Sculley, H. C. Zhou, Chem. Rev. 112 (2012) 869-932.

[3] Chun-Sen Liu, Jun-Jie Wang, Li-Fen Yan, Z. Chang, Xian-He Bu, E. C. Señudo, J. Ribas, Inorg. Chem. 46 (2007) 6299-6310.

[4] F. P. W. Agterberg, H. A, J. Kluit, W. L. Driessen, H. Oevering, W. Buijs, M. T. Lakin, A. L. Spek, J. Reedijk, Inorg. Chem. 36 (1997) 4321-4328.

[5] J. M. Rueff, N. Masciocchi, P. Rabu, A. Sironi, A. Skoulios, Eur. J. Inorg. Chem. (2001) 2843-2848.

[6] R. L. Rardin, A. Bino, P. Poganiuch, W. B. Tolman, S. Liu, S. J. Lippard, Angew. Chem. Int., Ed. Engl. 29 (1990) 842-844.

[7] M. Kato, Y. Muto, Coord. Chem. Rev. 92 (1988) 45-83.

[8] J. Moncol, M. Mudra, P. Lónnecke, M. Hewitt, M. Valko, H. Morris, J. Svorec, M. Melnik, M. Mazur, M. Koman, Inorg. Chim. Acta 360 (2007) 3213-3225

[9] F. Katzsch, A.S. Münch, F.O.R.L. Mertens, E. Weber; J. Molec. Struct. 1064 (2014) 122-129.

[10] H. K. Zhao, B. Ding, E. C. Yang, X. G. Wang, X. J. Zhao, Z. Anorg. Allg. Chem. 633 (2007) 1735-1738.

[11] N. Bouhmaida, M. A. Méndez-Rojas, A. Pérez-Benítez, G. Merino, B. Fraisse, N. E. Ghermani, Inorg. Chem. 49 (2010) 6443-6452.

[12] D. L. Reger, A. Debreczeni, M. D. Smith, J. Jezierska, A. Ozarowski, Inorg. Chem. 51 (2012) 1068-1083.

[13] V. Paredes-García, R. C. Santana, R. Madrid, A. Vega, E. Spodine, D. VenegasYazigi, Inorg. Chem. 52 (2013) 8369-8377.

[14] I.Y. Ahmed, A.L. Abu-Hijleh, Inorg. Chim. Acta 61 (1982) 241-246.

[15] A.L. Abu-Hijleh, Polyhedron 8 (1989) 2777-2783

[16] I. Uruska, J. Zielkewicz, J. Sol. Chem. 16 (1987) 145-154.

[17] B. Kozlevcar, A. Murn, K. Podlipnik, N. Lah, I. Leban, P. Segedin, Croat. Chem. Acta 77 (2004) 613-18.

[18] C.-H. Ge, X.-D. Zhang, W. Guan, Q.-T. Liu, J. Chem. Crystallogr. 36 (2006) 459464. 
[19] M. Guerrero, J.A. Ayllón, T. Calvet, M. Font-Bardía, J. Pons, Polyhedron 134 (2017) 107-113.

[20] J. Soldevila-Sanmartín, J.A. Ayllón, T. Calvet, M. Font-Bardía, J. Pons, Polyhedron 135 (2017) 36-40.

[21] J. Soldevila-Sanmartín, J.A. Ayllón, T. Calvet, M. Font-Bardía, J. Pons, Polyhedron 126 (2017) 184-194.

[22] H. Kumagai, M. Ohba, K. Inoue, H. Okawa, Chem. Letters 2002, 1006-1007.

[23] R.P. Sharma, A. Saini, S. Kumar, J. Kumar, P. Venugopalan, V.S. Gondil, S. Chhibber, T. Aree, Polyhedron 123 (2017) 430-440.

[24] C.J. Milios, R. Inglis, A. Vinslava, R. Bagai, W. Wernsdorfer, S. Parsons, S.P. Perlepes, G. Christou, E.K. Brechin, J. Am. Chem. Soc. 129 (2007) 12505-12511.

[25] R. Inglis, L.F. Jones, C.J. Milios, S. Datta, A. Collins, S. Parsons, W. Wernsdorfer, S. Hill, S.P. Perlepes, S. Piligkos, E.K. Brechin, Dalton Trans. (2009) 3403-3412.

[26] A.R. Dick, J.W. Kampf, M.S. Sanford, J. Am. Chem. Soc. 127 (2005) 1279012791.

[27] J.M. Racowski, A.R. Dick, M.S. Sanford, J. Am. Chem. Soc. 131 (2009) 1097410983.

[28] A. Ferguson, K. Thomson, A. Parkin, P. Cooper, C.J. Milios, E.K. Brechin, M. Murrie, Dalton Trans. (2007) 728-730.

[29] A. Ferguson, L.H. Thomas, M. Murrie, Polyhedron, 52 (2013) 227-233.

[30] K. Nakamoto, Infrared and Raman Spectra of Inorganic and Coordination Compounds. Applications in Coordination, Organometallic, and Bioinorganic Chemistry, sixth ed. Wiley-Interscience, New York, USA, 2009.

[31] G.B. Deacon, R.J. Phillips, Coord. Chem. Rev. 88 (1980) 227-250.

[32] J. A. Pérez, V. Montoya, J.A. Ayllón, M. Font-Bardía, T. Calvet, J. Pons, Inorg. Chim. Acta 394 (2013) 21-30.

[33] A.R. Katritzky, C.W. Ress, Comprehensive Heterocyclic Chemistry: THE Structure, Reactions, Synthesis, Uses of Heterocyclic Compounds, Pergamon Press, Oxford, UK, 1984.

[34] D.H. Williams, I. Fleming, Spectrocopic Methods in Organic Chemistry, McGrawHill, London, UK, 1995.

[35] E. Pretch, T. Clerc, J. Seibl, W. Simon, Tables of Determination of Organic Compounds. ${ }^{13} \mathrm{C}$ NMR, ${ }^{1} \mathrm{H}$ NMR, IR, MS,UV/Vis, Chemical Laboratory Practice, Springer, Berlin Germany, 1989. 
[36] J. Soldevila-Sanmartín, J.A. Ayllón, T. Calvet, M. Font-Bardía, J. Pons, Inorg. Chem. Commun. 71 (2016) 90-93.

[37] A.V. Yakovenko, S.V. Kolotilov, O. Cador, S. Golhen, L. Ouahab, V.V. Pavlishchuck, Eur. J. Inorg. Chem. (2009) 2354-2361.

[38] M. Barquín, N. Cocora, M.J.G. Garmendia, L. Larrínaga, E. Pinilla, M.R. Torres, J. Coord. Chem. 63 (2010) 2247-2260.

[39] K. Hassanein, O. Castillo, C.J. Gómez-García, F. Zamora, P. Amo-Ochoa, Cryst. Growth Des. 15 (2015) 5485-5494.

[40] M. Tas, A. Titiz, E. Karabag, M. Kaya, M. Ataseven, H. Dal. Synth. React. Inorg. Met. Org. Chem. 43 (2013) 1212-1223.

[41] W. Addison, T.N. Rao, J. Chem. Soc., Dalton Trans. (1984) 1349-1356.

[42] M. Sanchez-Sala, N. Portolés-Gil, O. Vallcorba, C. Domingo, A. López-Periago, J.A. Ayllón, ChemistrySelect. 1 (2016) 6692-6699.

[43] D. Singh, J. B. Baruah, Cryst. Growth Des. 12 (2012) 2109-21.

[44] A. Pramanik, S. Abbina, G. Das. Polyhedron 2007, 26, 5225-34.

[45] R. E. Del Sesto, A. M. Arif, J. S. Miller. Inorg. Chem. 39 (2000) 4894-4902.

[46] F. Hamza, G. Kickelbick, Macromolecules 42 (2009) 7762-7771.

[47] Z. Vasková, N. Kitanovski, Z. Jaglicic, P. Strauch, Z. Ruzickováf, D. Valigur, M. Koman, B. Kovlevkar, J. Moncol, Polyhedron 81 (2014) 555-563.

[48] N. Bozkurt, T. Tunç, N.C. Delibas, H. Necefoglu, T. Hökelek, Acta Cryst. E69 (2013) m458-m459.

[49] B. Bleaney, K.D. Bowers, Proc. R. Soc. London, Ser. A. 214 (1952) 451-465.

[50] M. Melnik, Coord. Chem. Rev. 42 (1982) 259-293.

[51] M. Sanchez-Sala, N. Portolés-Gil, O. Vallcorba, C. Domingo, A. Lopez-Periago, J.A. Ayllon, ChemistrySelect 1 (2016) 6692-6699.

[52] G.A. Bain, J.F. Berry. J. Chem. Ed. 85 (2008) 532-536.

[53] G. M. Sheldrick, Acta Cryst. C71 (2015) 3-8.

[54] C.F. Macrae, P.R. Edgington, P. McCabe, E. Pidcock, G. Shields, R. Taylor, M. Towler, J. van de Streek, J. Appl. Crystallogr. 39 (2006) 453-457.

[55] C.F. Macrae, I.J. Bruno, J.A. Chisholm, P.R. Edgington, P. McCabe, E. Pidcock, I. Rodriguez-Monge, R. Taylor, J. van de Streek, P.A. Wood, J. Appl. Crystallogr. 41 (2008) 466-470. 
Table 1. Selected bond lengths $(\AA)$ and bond angles $\left(^{\circ}\right)$ for 1-3

\begin{tabular}{|c|c|c|c|}
\hline 1 & & & \\
\hline \multicolumn{4}{|l|}{ Bond lengths $(\AA)$} \\
\hline $\mathrm{Cu}(1)-\mathrm{O}(4)$ & $1.9674(17)$ & $\mathrm{Cu}(1)-\mathrm{O}(2) \# 1$ & $1.9777(18)$ \\
\hline $\mathrm{Cu}(1)-\mathrm{O}(12)$ & $1.9681(17)$ & $\mathrm{Cu}(1)-\mathrm{N}(1)$ & $2.146(2)$ \\
\hline $\mathrm{Cu}(1)-\mathrm{O}(1)$ & $1.9717(18)$ & $\mathrm{Cu}(1)-\mathrm{Cu}(1) \# 1$ & $2.6198(5)$ \\
\hline \multicolumn{4}{|l|}{ Bond angles $\left(^{\circ}\right)$} \\
\hline $\mathrm{O}(4)-\mathrm{Cu}(1)-\mathrm{O}(12)$ & $168.97(7)$ & $\mathrm{O}(1)-\mathrm{Cu}(1)-\mathrm{O}(2) \# 1$ & $168.88(7)$ \\
\hline $\mathrm{O}(4)-\mathrm{Cu}(1)-\mathrm{O}(1)$ & $88.42(8)$ & $\mathrm{O}(4)-\mathrm{Cu}(1)-\mathrm{N}(1)$ & $97.97(8)$ \\
\hline $\mathrm{O}(12)-\mathrm{Cu}(1)-\mathrm{O}(1)$ & $89.51(8)$ & $\mathrm{O}(12)-\mathrm{Cu}(1)-\mathrm{N}(1)$ & $93.05(8)$ \\
\hline $\mathrm{O}(4)-\mathrm{Cu}(1)-\mathrm{O}(2) \# 1$ & $88.96(8)$ & $\mathrm{O}(1)-\mathrm{Cu}(1)-\mathrm{N}(1)$ & $97.74(8)$ \\
\hline $\mathrm{O}(12)-\mathrm{Cu}(1)-\mathrm{O} 2 \# 1$ & $91.00(8)$ & $\mathrm{O} 2 \# 1-\mathrm{Cu}(1)-\mathrm{N}(1)$ & $93.33(8)$ \\
\hline \multicolumn{4}{|l|}{2} \\
\hline \multicolumn{4}{|l|}{ Bond lengths $(\AA)$} \\
\hline $\mathrm{Cu}(1)-\mathrm{O}(4)$ & $1.9647(11)$ & $\mathrm{Cu}(1)-\mathrm{O}(2) \# 1$ & $1.9806(11)$ \\
\hline $\mathrm{Cu}(1)-\mathrm{O}(5) \# 1$ & $1.9726(11)$ & $\mathrm{Cu}(1)-\mathrm{N}(1)$ & $2.1682(13)$ \\
\hline $\mathrm{Cu}(1)-\mathrm{O}(1)$ & $1.9734(11)$ & $\mathrm{Cu}(1)-\mathrm{Cu}(1) \# 1$ & $2.6462(4)$ \\
\hline \multicolumn{4}{|l|}{ Bond angles $\left(^{\circ}\right)$} \\
\hline $\mathrm{O}(4)-\mathrm{Cu}(1)-\mathrm{O}(5) \# 1$ & $168.14(5)$ & $\mathrm{O}(1)-\mathrm{Cu}(1)-\mathrm{O}(2) \# 1$ & $168.18(5)$ \\
\hline $\mathrm{O}(4)-\mathrm{Cu}(1)-\mathrm{O}(1)$ & $89.92(5)$ & $\mathrm{O}(4)-\mathrm{Cu}(1)-\mathrm{N}(1)$ & $92.59(5)$ \\
\hline $\mathrm{O}(5) \# 1-\mathrm{Cu}(1)-\mathrm{O}(1)$ & $89.17(5)$ & $\mathrm{O}(5) \# 1-\mathrm{Cu}(1)-\mathrm{N}(1)$ & $99.26(5)$ \\
\hline $\mathrm{O}(4)-\mathrm{Cu}(1)-\mathrm{O}(2) \# 1$ & $89.17(5)$ & $\mathrm{O}(1)-\mathrm{Cu}(1)-\mathrm{N}(1)$ & $96.13(5)$ \\
\hline $\mathrm{O}(5) \# 1-\mathrm{Cu}(1)-\mathrm{O}(2) \# 1$ & $89.31(5)$ & $\mathrm{O}(2) \# 1-\mathrm{Cu}(1)-\mathrm{N}(1)$ & $95.69(5)$ \\
\hline \multicolumn{4}{|l|}{3} \\
\hline \multicolumn{4}{|l|}{ Bond lengths $(\AA)$} \\
\hline $\mathrm{Cu}(1)-\mathrm{O}(51)$ & $1.9819(18)$ & $\mathrm{Cu}(1)-\mathrm{O}(52) \#$ & $1.9596(18)$ \\
\hline $\mathrm{Cu}(1)-\mathrm{N}(11)$ & $2.144(2)$ & $\mathrm{Cu}(1)-\mathrm{O}(32) \#$ & $1.967(2)$ \\
\hline $\mathrm{Cu}(1)-\mathrm{O}(31)$ & $1.9659(19)$ & $\mathrm{Cu}(1)-\mathrm{Cu}(1) \#$ & $2.6524(6)$ \\
\hline \multicolumn{4}{|l|}{ Bond angles $\left(^{o}\right)$} \\
\hline $\mathrm{N}(11)-\mathrm{Cu}(1)-\mathrm{O}(51)$ & 93.33(8) & $\mathrm{O}(51)-\mathrm{Cu}(1)-\mathrm{O}(52)$ & $167.66(8)$ \\
\hline $\mathrm{N}(11)-\mathrm{Cu}(1)-\mathrm{O}(31)$ & $96.46(8)$ & $\mathrm{O}(51)-\mathrm{Cu}(1)-\mathrm{O}(32) \#$ & $90.64(9)$ \\
\hline $\mathrm{N}(11)-\mathrm{Cu}(1)-\mathrm{O}(52) \#$ & $99.00(8)$ & $\mathrm{O}(31)-\mathrm{Cu}(1)-\mathrm{O}(52)$ & $90.19(9)$ \\
\hline $\mathrm{N}(11)-\mathrm{Cu}(1)-\mathrm{O}(32) \#$ & 95.83(9) & $\mathrm{O}(31)-\mathrm{Cu}(1)-\mathrm{O}(32)$ & $167.70(8)$ \\
\hline $\mathrm{O}(31)-\mathrm{Cu}(1)-\mathrm{O}(51)$ & $88.35(8)$ & $\mathrm{O}(52)-\mathrm{Cu}(1)-\mathrm{O}(32) \#$ & $88.19(9)$ \\
\hline
\end{tabular}


Table 2. Selected bond lengths $(\AA)$ and bond angles $\left(^{\circ}\right)$ for $\mathbf{4}$ and $\mathbf{5}$

\begin{tabular}{|c|c|c|c|}
\hline 4 & & & \\
\hline \multicolumn{4}{|l|}{ Bond length $(\AA)$} \\
\hline $\mathrm{Cu}(1)-\mathrm{O}(51)$ & $1.977(3)$ & $\mathrm{Cu}(1)-\mathrm{O}(52) \#$ & $1.981(3)$ \\
\hline $\mathrm{Cu}(1)-\mathrm{N}(11)$ & $2.169(4)$ & $\mathrm{Cu}(1)-\mathrm{O}(32) \#$ & $1.956(3)$ \\
\hline $\mathrm{Cu}(1)-\mathrm{O}(31)$ & $1.967(3)$ & $\mathrm{Cu}(1)-\mathrm{Cu}(1) \#$ & $2.6579(10)$ \\
\hline \multicolumn{4}{|l|}{ Bond angles $\left(^{\circ}\right)$} \\
\hline $\mathrm{N}(11)-\mathrm{Cu}(1)-\mathrm{O}(31)$ & $100.13(13)$ & $\mathrm{N}(11)-\mathrm{Cu}(1)-\mathrm{O}(32) \#$ & $92.26(13)$ \\
\hline $\mathrm{N}(11)-\mathrm{Cu}(1)-\mathrm{O}(51)$ & $97.11(14)$ & $\mathrm{N}(11)-\mathrm{Cu}(1)-\mathrm{O}(52) \#$ & $94.71(13)$ \\
\hline $\mathrm{O}(31)-\mathrm{Cu}(1)-\mathrm{O}(51)$ & $90.05(12)$ & $\mathrm{O}(31)-\mathrm{Cu}(1)-\mathrm{O}(32) \#$ & $167.60(13)$ \\
\hline $\mathrm{O}(31)-\mathrm{Cu}(1)-\mathrm{O}(52) \#$ & $89.48(12)$ & $\mathrm{O}(51)-\mathrm{Cu}(1)-\mathrm{O}(52) \#$ & $168.07(12)$ \\
\hline $\mathrm{O}(32)-\mathrm{Cu}(1)-\mathrm{O}(51)$ & $88.51(13)$ & $\mathrm{O}(52) \#-\mathrm{Cu}(1)-\mathrm{O}(32) \#$ & $89.39(13)$ \\
\hline \multicolumn{4}{|l|}{5} \\
\hline \multicolumn{4}{|l|}{ Bond length $(\AA)$} \\
\hline $\mathrm{Cu}(1)-\mathrm{O}(11)$ & $1.9346(16)$ & $\mathrm{Cu}(1)-\mathrm{O}(10)$ & $2.266(3)$ \\
\hline $\mathrm{Cu}(1)-\mathrm{N}(31)$ & $2.027(2)$ & & \\
\hline \multicolumn{4}{|l|}{ Bond angles $\left(^{o}\right)$} \\
\hline $\mathrm{O}(11)-\mathrm{Cu}(1)-\mathrm{N}(31) \#$ & $90.58(7)$ & $\mathrm{N}(31)-\mathrm{Cu}(1)-\mathrm{O}(10)$ & $97.21(6)$ \\
\hline $\mathrm{O}(11)-\mathrm{Cu}(1)-\mathrm{O}(10)$ & $87.83(5)$ & $\mathrm{O}(11)-\mathrm{Cu}(1)-\mathrm{N}(31)$ & $89.96(7)$ \\
\hline $\mathrm{O}(11)-\mathrm{Cu}(1)-\mathrm{O}(11) \#$ & $175.67(10)$ & $\mathrm{N}(31)-\mathrm{Cu}(1)-\mathrm{N}(31) \#$ & $165.57(11)$ \\
\hline
\end{tabular}

4: \#-x, 2-y, 2-z; 5: \#-x, y, 1/2-z 
Table 3. Distances $(\AA)$ and angles $\left(^{\circ}\right)$ related to hydrogen bonding interaction in complexes 1-5

\begin{tabular}{|l|l|l|l|l|}
\hline $\mathrm{D}-\mathrm{H} \cdots \mathrm{A}$ & $\mathrm{H} \cdots \mathrm{A}$ & $\mathrm{D} \cdots \mathrm{A}$ & $>\mathrm{D}-\mathrm{H} \cdots \mathrm{A}$ & Symmetry \\
\hline $\mathbf{1}$ & & & & \\
\hline $\mathrm{C}(30)-\mathrm{H}(30) \cdots \mathrm{O}(3)$ & 2.47 & $3.3518(4)$ & 158 & $\mathrm{x}, 1 / 2-\mathrm{y},-1 / 2+\mathrm{z}$ \\
\hline $\mathrm{C}(9)-\mathrm{H}(9) \cdots \mathrm{O}(1)$ & 2.52 & $3.4017(3)$ & 159 & $-1 / 2-\mathrm{x},-1 / 2+\mathrm{y}, \mathrm{z}$ \\
\hline $\mathrm{C}(11)-\mathrm{H}(11) \cdots \mathrm{O}(2)$ & 2.59 & $3.3612(3)$ & 141 & $-\mathrm{x},-\mathrm{y}, 1-\mathrm{z}$ \\
\hline & & & & \\
\hline $\mathbf{2}$ & & & & \\
\hline $\mathrm{C}(19)-\mathrm{H}(19) \cdots \mathrm{O}(6)$ & 2.63 & $3.427(2)$ & 142 & $-\mathrm{x}, 2-\mathrm{y}, 1-\mathrm{z}$ \\
\hline $\mathbf{3}$ & & & & \\
\hline $\mathrm{C}(15)-\mathrm{H}(15) \cdots \mathrm{O}(40)$ & 2.46 & $3.098(4)$ & 126 & $\mathrm{x}, 1+\mathrm{y}, \mathrm{z}$ \\
\hline $\mathrm{C}(16)-\mathrm{H}(16) \cdots \mathrm{O}(40)$ & 2.57 & $3.165(4)$ & 122 & $\mathrm{x}, 1+\mathrm{y}, \mathrm{z}$ \\
\hline $\mathbf{4}$ & & & & \\
\hline $\mathrm{C}(53)-\mathrm{H}(53) \cdots \mathrm{O}(40)$ & 2.37 & $3.266(9)$ & 161 & $\mathrm{x}, \mathrm{y}, 1+\mathrm{z}$ \\
\hline $\mathbf{5}$ & & & & $-\mathrm{x},-1+\mathrm{y}, 1 / 2-\mathrm{z}$ \\
\hline $\mathrm{O}(10)-\mathrm{H}(10 \mathrm{~A}) \cdots \mathrm{O}(12)$ & $2.00(3)$ & $2.801(3)$ & $165(3)$ & \\
\hline
\end{tabular}


Table 4. Crystallographic data for 1-3

\begin{tabular}{|c|c|c|c|}
\hline & $\mathbf{1}$ & 2 & 3 \\
\hline Empirical formula & $\mathrm{C}_{62} \mathrm{H}_{46} \mathrm{~N}_{2} \mathrm{O}_{12} \mathrm{Cu}_{2}$ & $\mathrm{C}_{74} \mathrm{H}_{54} \mathrm{~N}_{2} \mathrm{O}_{12} \mathrm{Cu}_{2}$ & $\mathrm{C}_{76} \mathrm{H}_{58} \mathrm{~N}_{2} \mathrm{O}_{12} \mathrm{Cu}_{2}$ \\
\hline Formula weigh & 1138.09 & 1290.27 & 1318.32 \\
\hline$T(\mathrm{~K})$ & $100(2)$ & $100(2)$ & 296(2) K \\
\hline Wavelength $(\AA)$ & 0.71073 & 0.71073 & 0.71073 \\
\hline System, space group & Orthorhombic, Pbca & Monoclinic, $\mathrm{P} 2{ }_{1} / \mathrm{c}$ & Triniclic, $\mathrm{P}(-1)$ \\
\hline \multicolumn{4}{|l|}{ Unit cell dimensions } \\
\hline$a(\AA)$ & $18.8664(6)$ & $16.0567(6)$ & $9.5014(6)$ \\
\hline$b(\AA)$ & $13.8772(5)$ & $10.9762(4)$ & $11.8607(8)$ \\
\hline$c(\AA)$ & $19.2692(6)$ & $18.3963(7)$ & $15.1391(10)$ \\
\hline$\alpha\left(^{\circ}\right)$ & 90 & 90 & $78.8200(10)$ \\
\hline$\beta\left(^{\circ}\right)$ & 90 & $114.9700(10)$ & $82.0830(10)$ \\
\hline$\gamma\left(\left(^{\circ}\right)\right.$ & 90 & 90 & $82.7450(10)$ \\
\hline $\mathrm{V}\left(\AA^{3}\right)$ & $5044.9(3)$ & 2939.14192) & 1649.02(19) \\
\hline$Z$ & 4 & 2 & 1 \\
\hline Dcalc $\left(\mathrm{g} \mathrm{cm}^{3}\right)$ & 1.498 & 1.458 & 1.328 \\
\hline$\mu\left(\mathrm{mm}^{-1}\right)$ & 0.914 & 0.794 & 0.709 \\
\hline$F(000)$ & 2344 & 1332 & 682 \\
\hline Crystal size $\left(\mathrm{mm}^{3}\right)$ & $0.384 \times 0.353 \times 0.268$ & $0.271 \times 0.181 \times 0.142$ & $0.350 \times 0.200 \times 0.150$ \\
\hline$h k l$ ranges & $\begin{array}{l}-26 \leq \mathrm{h} \leq 23 \\
-17 \leq \mathrm{k} \leq 19 \\
-27 \leq 1 \leq 26\end{array}$ & $\begin{array}{l}-22 \leq \mathrm{h} \leq 22 \\
-15 \leq \mathrm{k} \leq 15 \\
-26 \leq 1 \leq 26\end{array}$ & $\begin{array}{l}-12 \leq \mathrm{h} \leq 12 \\
-15 \leq \mathrm{k} \leq 16 \\
-20 \leq \mathrm{l} \leq 20\end{array}$ \\
\hline $2 \theta$ range $\left(^{\circ}\right)$ & 2.106 to 30.548 & 2.245 to 30.552 & 1.759 to 28.808 \\
\hline $\begin{array}{l}\text { Reflections collected/ } \\
\text { unique/[Rint] }\end{array}$ & $\begin{array}{l}52601 / 7667 /[\text { Rint }]= \\
0.0268\end{array}$ & $\begin{array}{l}115395 / 8992 / \\
{[\text { Rint }]=0.0493}\end{array}$ & $\begin{array}{l}13286 / 7666 /[\text { Rint }]= \\
0.0247\end{array}$ \\
\hline $\begin{array}{l}\text { Completeness to } \theta= \\
25.240\end{array}$ & $99.2 \%$ & $99.9 \%$ & $99.2 \%$ \\
\hline Absorption Correction & Semi-empirical & Semi-empirical & Semi-empirical \\
\hline Max. and min. transmis. & 0.7461 and 0.6719 & 0.7461 and 0.6997 & 1 and 0.856 \\
\hline Refinement method & $\begin{array}{l}\text { Full matrix least- } \\
\text { squares on } \mathrm{F}^{2}\end{array}$ & $\begin{array}{l}\text { Full matrix least- } \\
\text { squares on } \mathrm{F}^{2}\end{array}$ & $\begin{array}{l}\text { Full matrix least- } \\
\text { squares on } \mathrm{F}^{2}\end{array}$ \\
\hline $\begin{array}{l}\text { Data/restrains/parameter } \\
\text { s }\end{array}$ & $7667 / 1 / 353$ & $8992 / 2 / 406$ & $7666 / 18 / 415$ \\
\hline $\begin{array}{l}\text { Goodness of fit (GOF) } \\
\text { on } F^{2}\end{array}$ & 1.184 & 1.111 & 1.016 \\
\hline Final $R$ indices $[I>2 \sigma(I)]$ & $\begin{array}{l}\mathrm{R} 1=0.0549 \\
\mathrm{wR} 2=0.1527\end{array}$ & $\begin{array}{l}\mathrm{R} 1=0.0349 \\
\mathrm{wR} 2=0.0888\end{array}$ & $\begin{array}{l}\mathrm{R} 1=0.0513 \\
\mathrm{wR} 2=0.1243\end{array}$ \\
\hline$R$ indices (all data) & $\begin{array}{l}\mathrm{R} 1=0.0697 \\
\mathrm{wR} 2=0.1684\end{array}$ & $\begin{array}{l}\mathrm{R} 1=0.0498 \\
\mathrm{wR} 2=0.1000\end{array}$ & $\begin{array}{l}\mathrm{R} 1=0.0895 \\
\mathrm{wR} 2=0.1424\end{array}$ \\
\hline Extinction coefficient & $0.0217(11)$ & $\mathrm{n} / \mathrm{a}$ & $\mathrm{n} / \mathrm{a}$ \\
\hline $\begin{array}{l}\text { Largest. Diff. peak and } \\
\text { hole }\left(\mathrm{e} \AA^{-3}\right)\end{array}$ & 1.230 and -0.806 & 0.590 and -0.494 & 0.313 and -0.186 \\
\hline
\end{tabular}


Table 5. Crystallographic data for $\mathbf{4}$ and $\mathbf{5}$

\begin{tabular}{|c|c|c|}
\hline & 4 & 5 \\
\hline Empirical formula & $\mathrm{C}_{74} \mathrm{H}_{54} \mathrm{~N}_{2} \mathrm{O}_{12} \mathrm{Cu}_{2}$ & $\mathrm{C}_{48} \mathrm{H}_{38} \mathrm{~N}_{2} \mathrm{O}_{7} \mathrm{Cu}$ \\
\hline Formula weigh & 1290.27 & 818.34 \\
\hline$T(\mathrm{~K})$ & $296(2)$ & $296(2)$ \\
\hline Wavelength $(\AA)$ & 0.71073 & 0.71073 \\
\hline System, space group & Triclinic, $\mathrm{P}(-1)$ & Monoclinic, C2/c \\
\hline \multicolumn{3}{|l|}{ Unit cell dimensions } \\
\hline$a(\AA)$ & $11.0460(10)$ & $26.0381(19)$ \\
\hline$b(\AA)$ & $11.1196(10)$ & $5.9756(4)$ \\
\hline$c(\AA)$ & $13.1169(12)$ & $26.0895(19)$ \\
\hline$\alpha\left(^{\circ}\right)$ & $81.776(2)$ & 90 \\
\hline$\beta\left(^{\circ}\right)$ & $77.644(2)$ & $97.168(1)$ \\
\hline$\gamma\left({ }^{\circ}\right)$ & $82.277(2)$ & 90 \\
\hline $\mathrm{V}\left(\AA^{3}\right)$ & $1548.6(2)$ & $4027.6(5)$ \\
\hline$Z$ & 1 & 4 \\
\hline Dcalc $\left(\mathrm{g} \mathrm{cm}^{3}\right)$ & 1.384 & 1.350 \\
\hline$\mu\left(\mathrm{mm}^{-1}\right)$ & 0.754 & 0.598 \\
\hline$F(000)$ & 666 & 1700 \\
\hline Crystal size $\left(\mathrm{mm}^{3}\right)$ & $0.23 \times 0.17 \times 0.15$ & $0.18 \times 0.15 \times 0.11$ \\
\hline$h k l$ ranges & $\begin{array}{l}-14 \leq \mathrm{h} \leq 14 \\
-14 \leq \mathrm{k} \leq 14 \\
-17 \leq \mathrm{l} \leq 17\end{array}$ & $\begin{array}{l}-34 \leq \mathrm{h} \leq 34 \\
-7 \leq \mathrm{k} \leq 7 \\
-34 \leq \mathrm{l} \leq 33\end{array}$ \\
\hline $2 \theta$ range $\left(^{\circ}\right)$ & 1.600 to 28.730 & 1.573 to 28.908 \\
\hline $\begin{array}{l}\text { Reflections collected/ } \\
\text { unique/[Rint] }\end{array}$ & $\begin{array}{l}12529 / 7208 / \\
{[\text { Rint }]=0.0528}\end{array}$ & $\begin{array}{l}14933 / 4850 /[\text { Rint }] \\
=0.0506\end{array}$ \\
\hline $\begin{array}{l}\text { Completeness to } \theta= \\
25.240\end{array}$ & $99.4 \%$ & $99.5 \%$ \\
\hline Absorption Correction & Semi-empirical & Semi-empirical \\
\hline Max. and min. transmis. & 0.893 and 0.700 & 0.936 and 0.707 \\
\hline Refinement method & $\begin{array}{l}\text { Full matrix least- } \\
\text { squares on } \mathrm{F}^{2}\end{array}$ & $\begin{array}{l}\text { Full matrix least- } \\
\text { squares on } \mathrm{F}^{2}\end{array}$ \\
\hline $\begin{array}{l}\text { Data/restrains/parameter } \\
\mathrm{s}\end{array}$ & $7208 / 18 / 406$ & $4850 / 6 / 267$ \\
\hline $\begin{array}{l}\text { Goodness of fit (GOF) } \\
\text { on } F^{2}\end{array}$ & 0.978 & 1.003 \\
\hline Final $R$ indices $[I>2 \sigma(I)]$ & $\begin{array}{l}\mathrm{R} 1=0.0707 \\
\mathrm{wR} 2=0.1412\end{array}$ & $\begin{array}{l}\mathrm{R} 1=0.0508 \\
\mathrm{wR} 2=0.1167\end{array}$ \\
\hline$R$ indices (all data) & $\begin{array}{l}\mathrm{R} 1=0.1566 \\
\mathrm{wR} 2=0.1745\end{array}$ & $\begin{array}{l}\mathrm{R} 1=0.0847 \\
\mathrm{wR} 2=0.1310\end{array}$ \\
\hline Extinction coefficient & $\mathrm{n} / \mathrm{a}$ & $\mathrm{n} / \mathrm{a}$ \\
\hline $\begin{array}{l}\text { Largest. Diff. peak and } \\
\text { hole }\left(\mathrm{e} \AA^{-3}\right)\end{array}$ & 0.369 and -0.435 & 384 and -0.351 \\
\hline
\end{tabular}




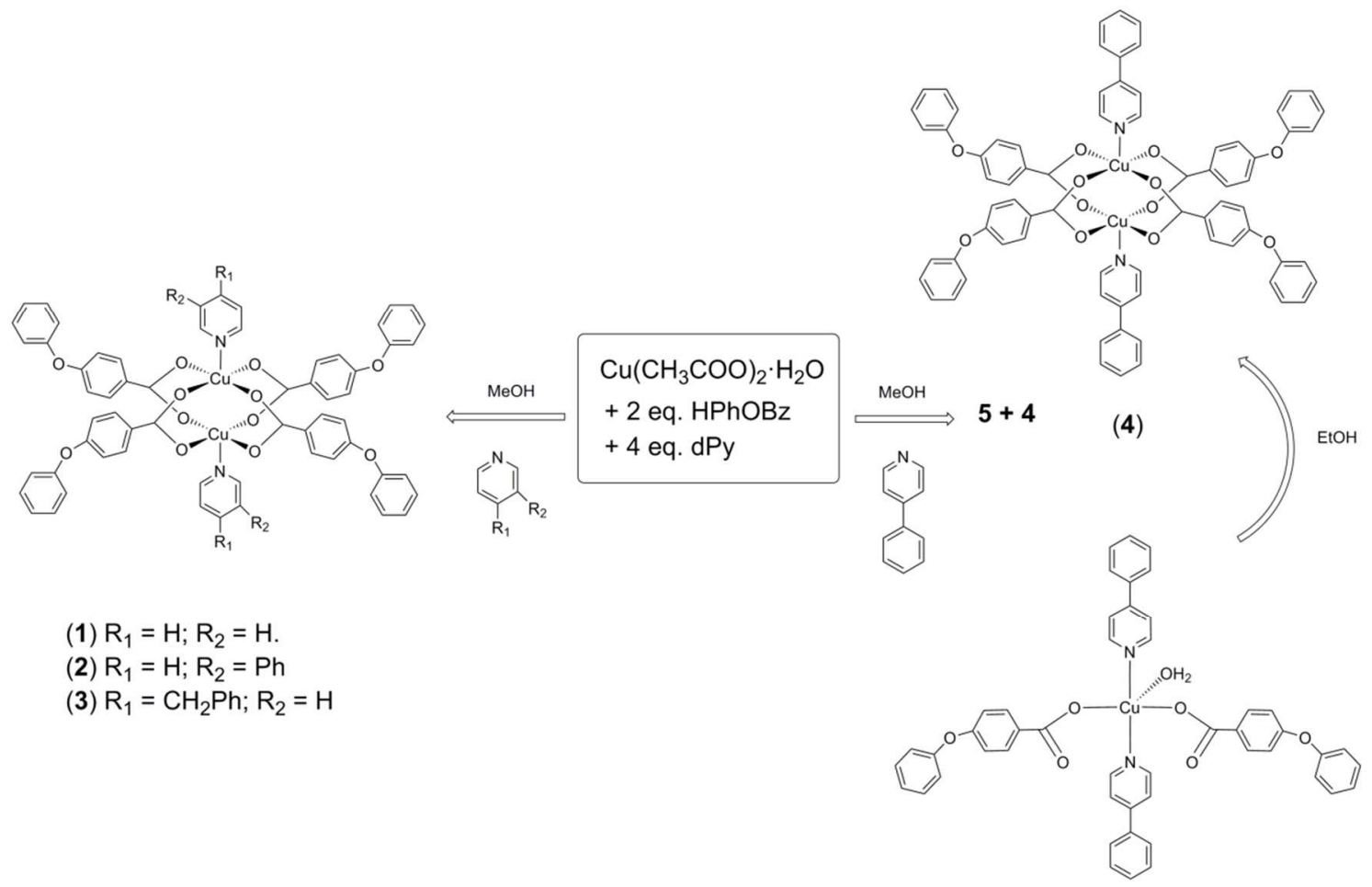

(5)

Scheme 1. Scheme of the reactions carried out in this work. Isolated and characterized products are shown with their numbering scheme. 

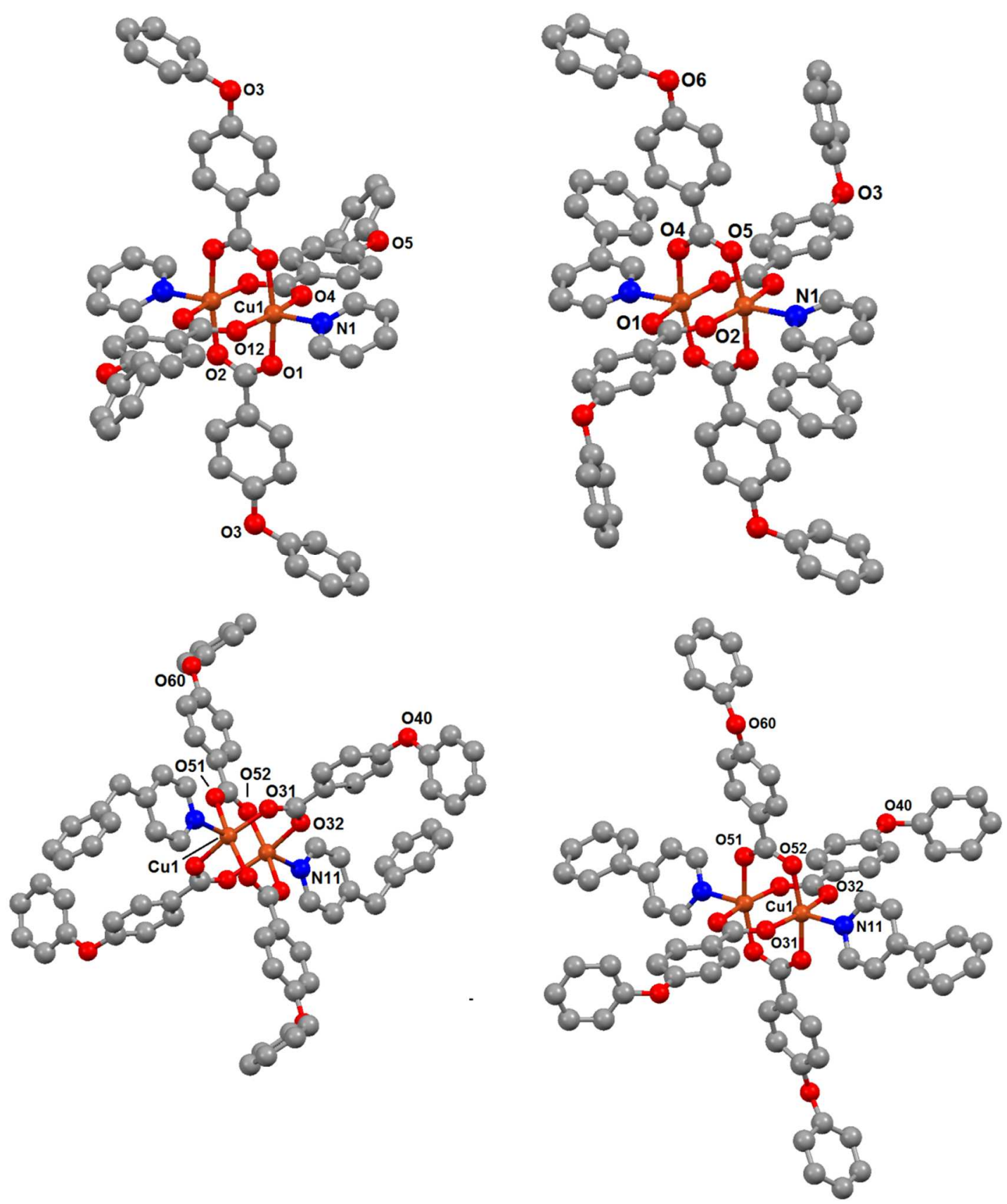

Figure 1. $\left[\mathrm{Cu}(\mathrm{PhOBz})_{2}(\mathrm{py})\right]_{2}$ (1, up, left $)$ and $\left[\mathrm{Cu}(\mathrm{PhOBz})_{2}(3-\mathrm{Phpy})\right]_{2}$ (2, up, right) $\left[\mathrm{Cu}(\mathrm{PhOBz})_{2}\left(4-\mathrm{PhCH}_{2} \mathrm{py}\right)\right]_{2}(\mathbf{3}$, down left $)$ and $\left[\mathrm{Cu}(\mathrm{PhOBz})_{2}(4-\mathrm{Phpy})\right]_{2}$ (4, down rigth), showing all non-hydrogen atoms and the atom numbering scheme. 


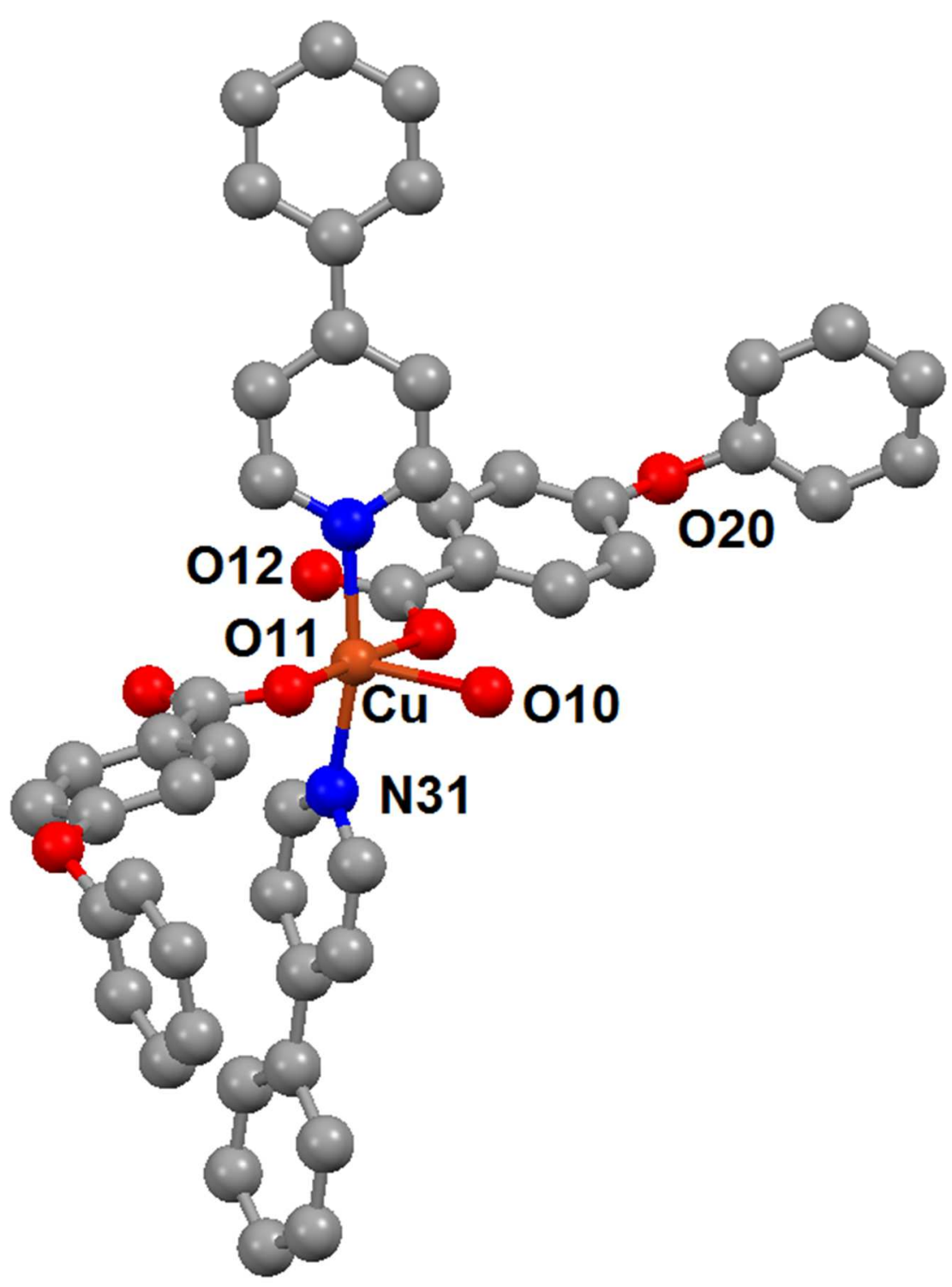

Figure 2. $\left[\mathrm{Cu}(\mathrm{PhOBz})_{2}(4-\mathrm{Phpy})_{2}\left(\mathrm{H}_{2} \mathrm{O}\right)\right](5)$, showing all non-hydrogen atoms and the atom numbering scheme. 

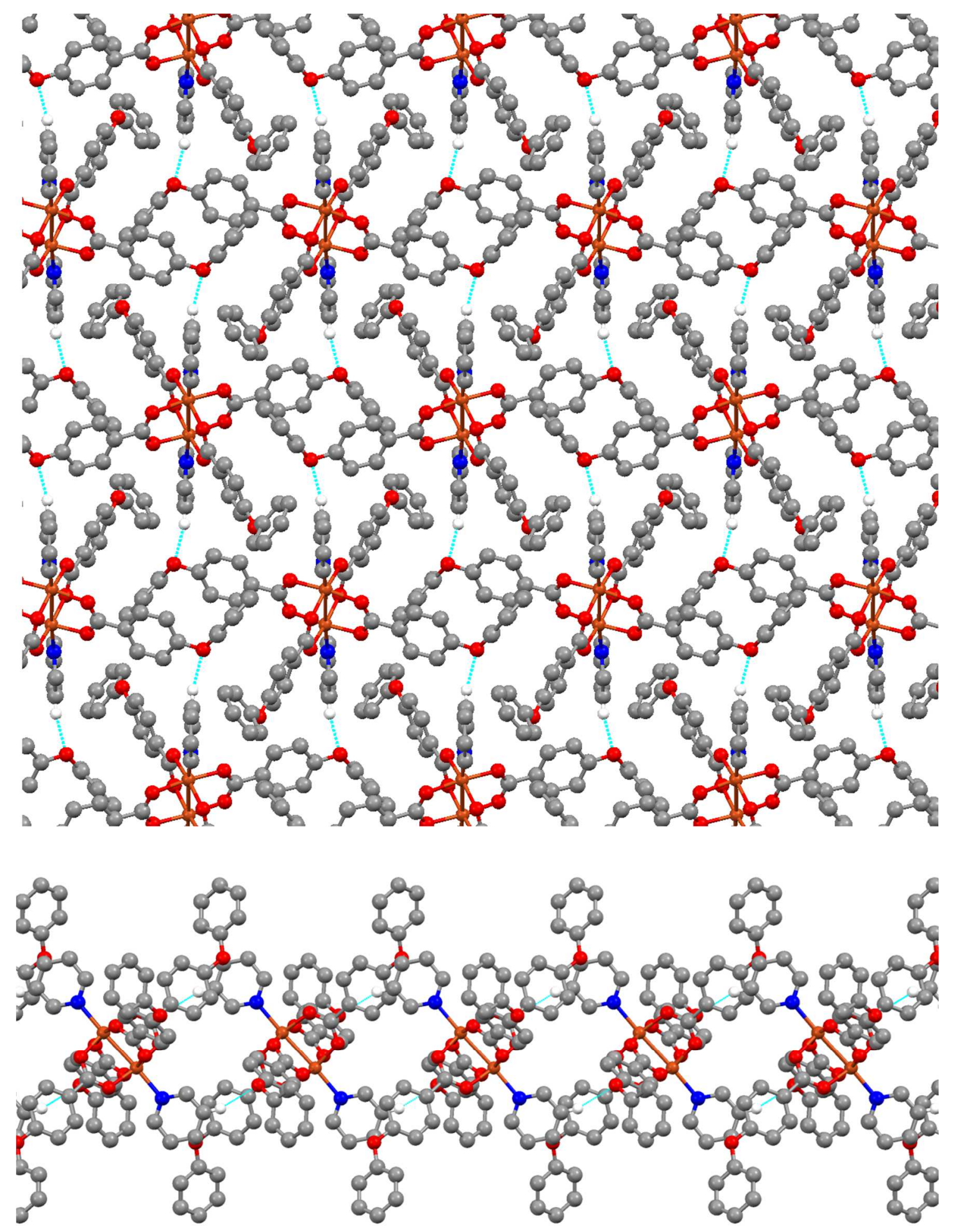

Figure 3. 2D supramolecular sheets formed by the propagation of the $\mathrm{C}(30)$ $\mathrm{H}(30) \cdots \mathrm{O}(3)$ hydrogen bond (green line) in compound 1 (up) view along $a$; (down) transversal view along $b$. 

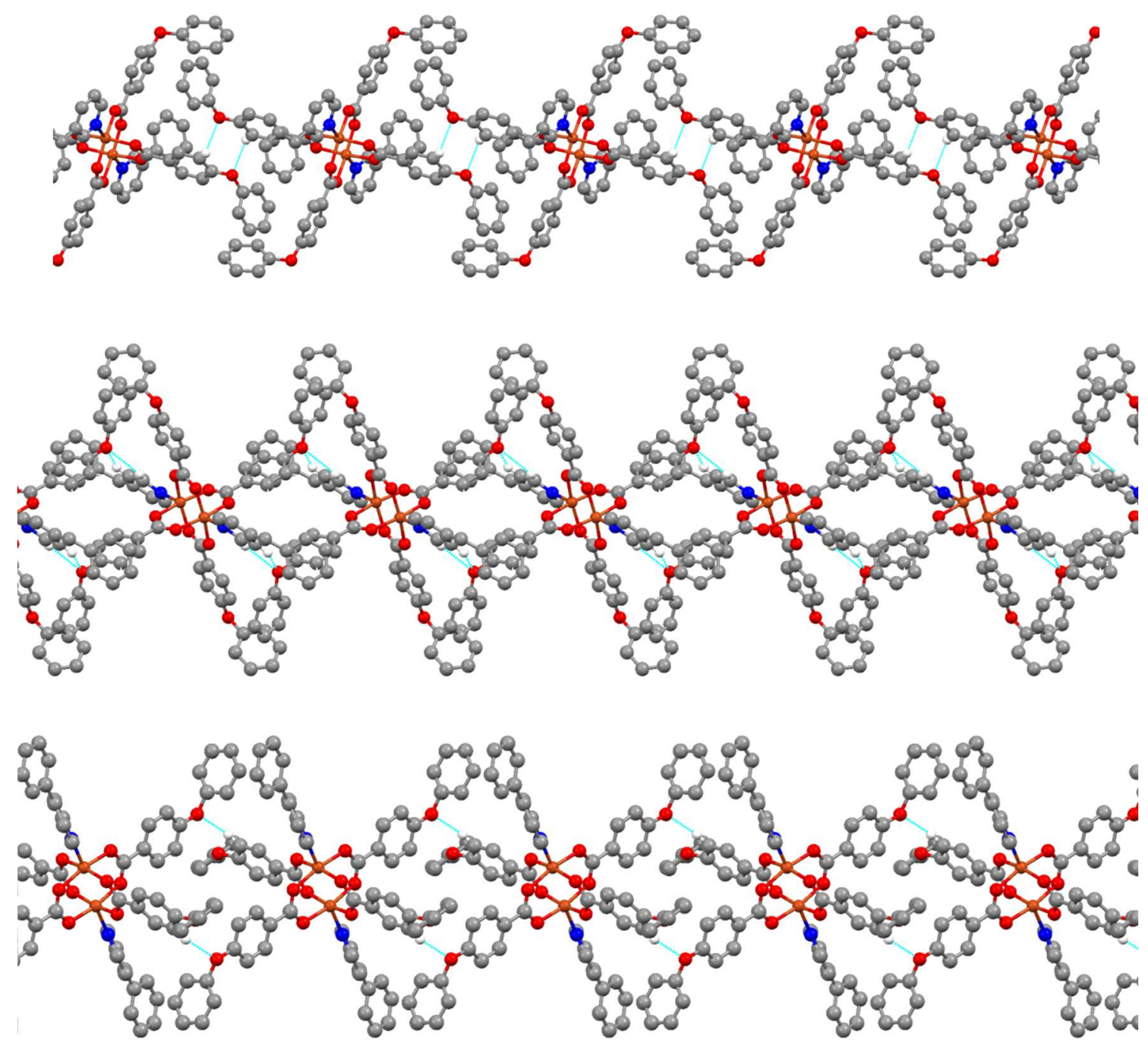

Figure 4. 1D supramolecular chains formed by the propagation of the hydrogen bond (green line) in compounds $\mathbf{2}$ (up), $\mathbf{3}$ (middle) and $\mathbf{4}$ (down). Hydrogens not participating in intermolecular contacts were omitted for clarity. 


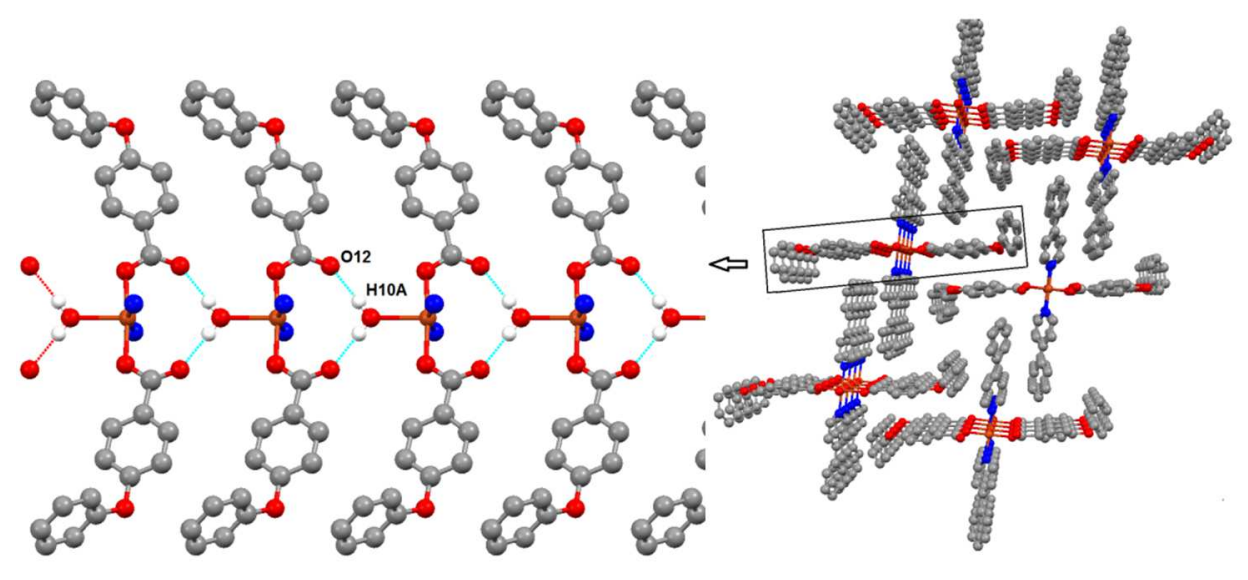

Figure 5. Extended crystal structure $\left[\mathrm{Cu}(\mathrm{PhOBz})_{2}(4-\mathrm{Phpy})_{2}\left(\mathrm{H}_{2} \mathrm{O}\right)\right](5)$. (left) detailed one-dimensional chain propagation generated by intermolecular hydrogen bonds between water and carboxylate ligands. Only $\mathrm{N}$ atoms of 4-Phpy are depicted for clarity. (right) Perspective projection along the $b$ axis.

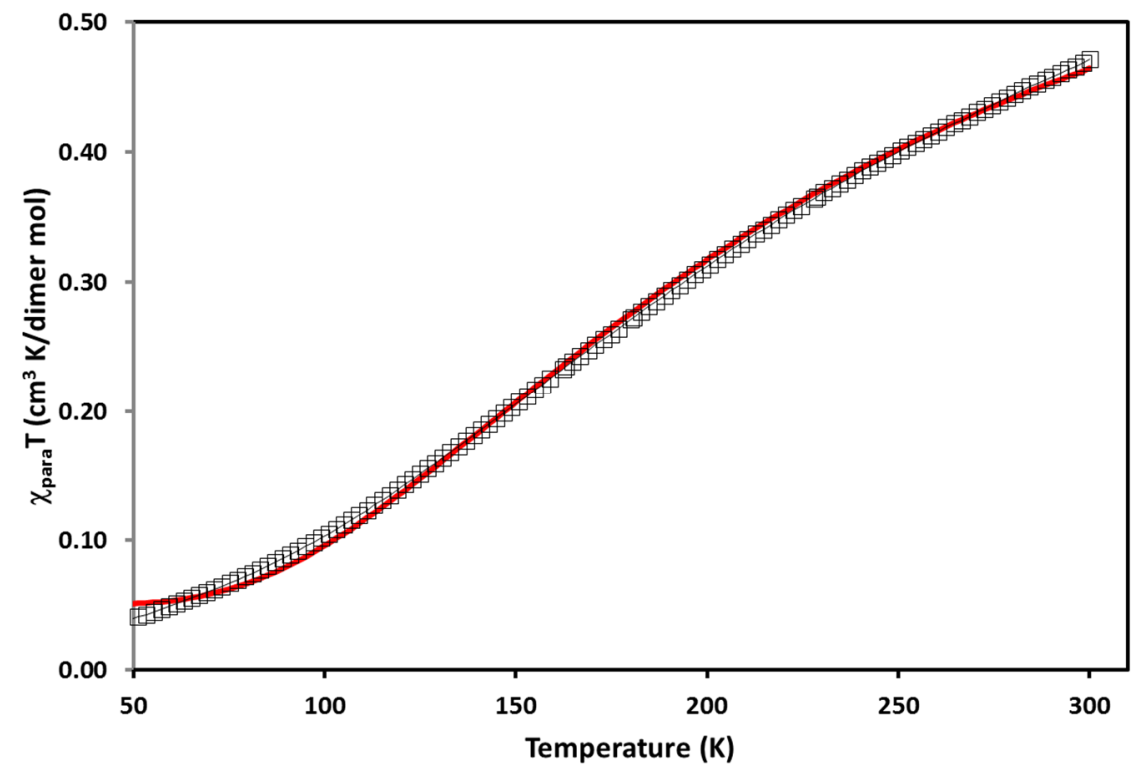

Figure 6. Thermal variation of $\chi_{\mathrm{m}} \mathrm{T}$ for complex $\left[\mathrm{Cu}(\mathrm{PhOBz})_{2}(4-\mathrm{Phpy})_{2}\left(\mathrm{H}_{2} \mathrm{O}\right)\right](5)$. Solid red line is the best fit to the $\mathrm{S}=1 / 2$ dimer model. 

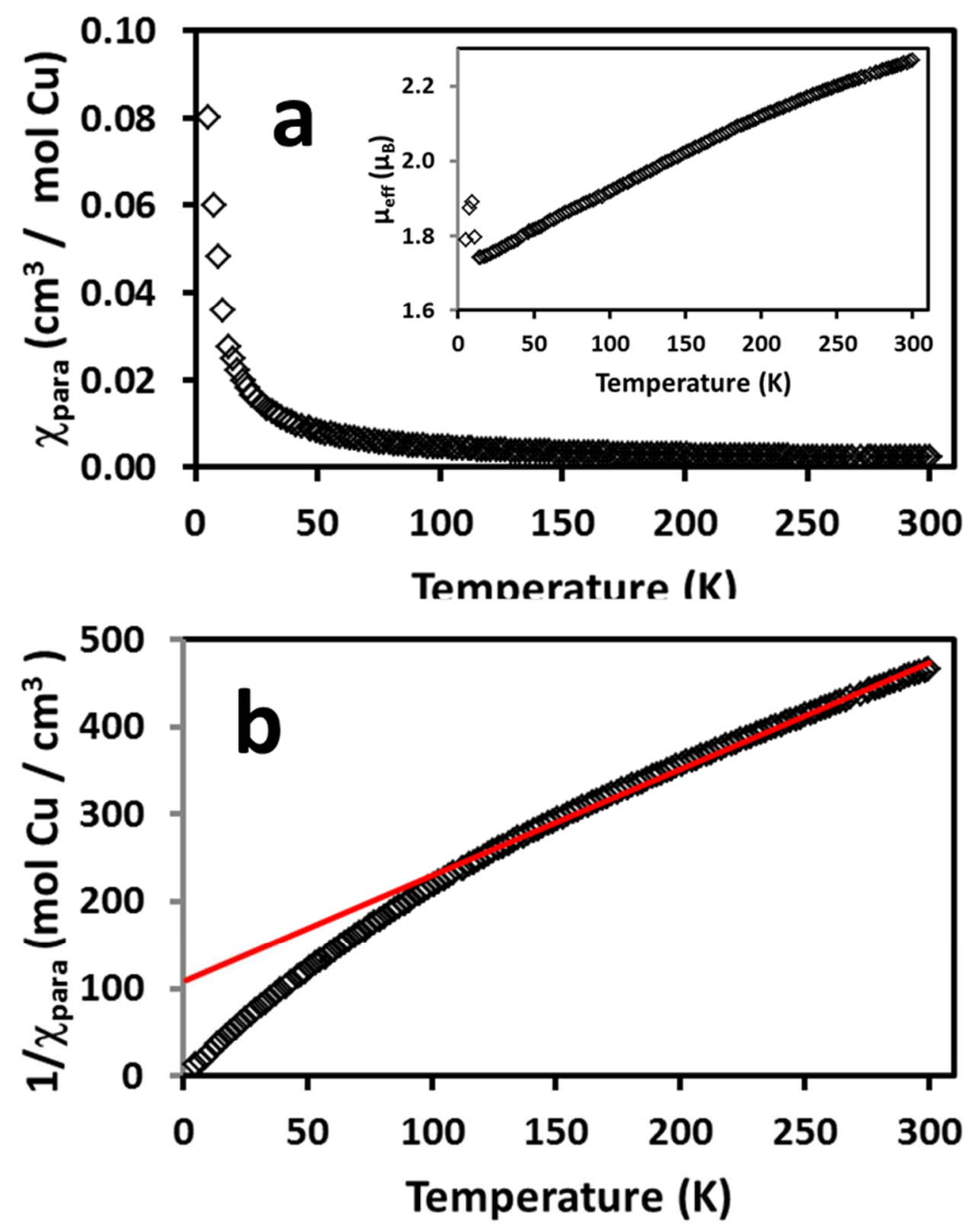

Figure 7. Magnetic characterization of $\left[\mathrm{Cu}(\mathrm{PhOBz})_{2}(\mathrm{PhPy})_{2}\left(\mathrm{H}_{2} \mathrm{O}\right)\right]$ (5): (a) Thermal variation of $\chi_{\mathrm{p}}$. Inset shows the values of $\mu_{\mathrm{eff}}$, and (b) Thermal variation of $1 / \chi_{\mathrm{p}}$. Solid red line is the best fit to the Curie-Weiss equation with $\mathrm{C}=0.820 \mathrm{emu} \cdot \mathrm{K} \cdot \mathrm{mol}^{-1}$, and $\theta=-$ $88 \mathrm{~K}$. 